\title{
INFLUENŢA EXTRACTELOR BIOACTIVE DIN SPIRULINĂ ASUPRA CONSERVĂRII MICROORGANISMELOR
}

\author{
Batîr Ludmila, Slanina Valerina \\ Institutul de Microbiologie şi Biotehnologie, Chișinău, Republica Moldova \\ e-mail:batludmila@mail.ru
}

Tulpinile de microorganisme, utilizate în biotehnologie prezintă valoare economică şi comercială, iar problema menţinerii cât mai îndelungate a proprietăţilor biosintetice a microorganismelor şi celor economic valoroase este permanent în atenţia savanţilor. Păstrarea microorganismelor şi proprietăţilor acestora necesită utilizarea metodelor eficiente de conservare şi monitorizare permanentă a eficacităţii acestor metode. Metodele de conservare şi depozitare a microorganismelor sunt importante pentru orice investigaţie microbiologică, însă cel mai important rol în procesul de liofilizare a microorganismelor este selectarea mediului optimal de protecţie (conservantului).

Astfel, pentru noi a prezentat interes studiul acţiunii conservanţilor naturali extraşi din biomasa cianobacteriei Spirulina platensis în calitate de agenţi de protecţie a microorganismelor din colecţie în vederea menţinerii cît mai îndelungate a proprietăţilor culturale caracteristice, deoarece, cu utilizarea mediilor standard de menţinere a microorganismelor are loc pierderea în timp a capacităţii şi activităţii caracteristice acestora. Utilizarea în acest sens a complexelor policomponente extrase din biomasa de spirulină ce posedă activitate antioxidantă şi antiradicalică înaltă prezintă interes datorită substanţelor bioactive pe care le conţine spirulina, recunoscute ca conservanţi naturali.

În baza biomasei cianobacteriei Spirulina platensis au fost obţinute 5 extracte bioactive cu activitatea antioxidantă şi antiradicalică sporită utilizate în calitate de agenți protectori în procesul de liofilizare a unor tulpini de bacterii din CNMN de interes biotehnologic. Rezultatele obţinute au permis de a stabili că acţiune benefică de stimulare posedă majoritatea extractelor bioactive atât până, cât şi după liofilizare.

Astfel, în urma cercetărilor efectuate, asupra determinării viabilităţii tulpinilor de bacterii din g. Pseudomonas până şi după liofilizare, cu şi fără utilizarea extractelor bioactive obţinute din biomasa de spirulină, am stabilit că toate extractele au efect pozitiv, cu excepţia extractelor etanolice, care după liofilizare duc la scăderea viabilităţii cu până la 7,6 - 9,3\%, în dependenţă de tulpina studiată. Cel mai eficient extract în protejarea culturilor date s-a dovedit a fi cel glucidic care menţine valorile viabilităţii majorate atât până la liofilizare cât şi după acest proces, sporul fiind de cca 9,0\%.

Un alt grup de bacterii testate, de interes biotehnologic, au fost cele din g. Bacillus. Datele obţinute asupra cultivării tulpinii Bacillus subtilis CNMN-BB-01 în prezenţa extractelor bioactive, până la liofilizare au permis de a conchide şi în acest caz că toate preparatele policomponente posedă efect pozitiv, extractele etanolice variind în limita martorului celelalte tinzând spre o creştere neesenţială în dependenţă de concentraţia utilizată în studiu.

Spre deosebire de tulpina Bacillus subtilis CNMN-BB-01, tulpina Bacillus cereus var. fluorescens CNMN-BB-07 a reacţionat diferit la prezenţa în mediu a extractelor bioactive. Astfel, viabilitatea acesteia până la liofilizare cu utilizarea extractelor etanolice a tins spre o scădere neesenţială cu până la $4,9 \%$, faţă de proba martor. Extractele proteo-glucidic (5\%) şi glucidic (de 5 şi $10 \%)$ au avut efect stimulator asupra viabilităţii valorile date crescând cu până la 5,5\%. Rezultatele obţinute după liofilizare au demonstrat că extractul proteic de $5 \%$ a avut cel mai bun efect ce a dus la sporirea viabilităţii cu până la 7,7\%, faţă de control.

În final putem conchide că extractele biologic active extrase din biomasa cianobacteriei Spirulina platensis CNMN-CB-11 pot fi utilizate în calitate de protectori ai tulpinilor de bacterii însă activitatea lor depinde de concentraţia utilizată şi tulpina testată. 